\title{
TRANSFORMASI CERITA KOLONIAL DALAM TEKS “ORANG RANTAI"
}

\section{TRANSFORMING COLONIAL STORIES IN TEXT "ORANG RANTAI"}

\author{
Yosi Wulandari ${ }^{1}$, Wachid Eko Purwanto $^{2}$, Fitri Merawati ${ }^{3}$ \\ ${ }^{1)}$ Universitas Ahmad Dahlan, Jalan Ring Road Selatan, Tamanan, Bantul, \\ yosi.wulandari@pbsi.uad.ac.id \\ ${ }^{2)}$ Universitas Ahmad Dahlan, Jalan Ring Road Selatan, Tamanan, Bantul, \\ wachid.purwanto@pbsi.uad.ac.id \\ ${ }^{3)}$ Universitas Ahmad Dahlan, Jalan Ring Road Selatan, Tamanan, Bantul, \\ fitri.merawati@pbsi.uad.ac.id
}

\begin{abstract}
ABSTRAK
Tujuan penelitian ini adalah untuk mendeskripsikan (1) resepsi penulis terhadap wacana kolonial dalam teks "Orang Rantai"; (2) bentuk-bentuk transformasi cerita kolonial dalam teks "Orang Rantai". Pendekatan penelitian ini adalah intertekstualitas dengan penerapan teori resepsi sastra Hans Robert Jauss. Objek penelitian ini adalah cerita "Orang Rantai. Subjek penelitian ini adalah buku cerita "Orang Rantai" yang ditulis oleh TIM Dosen Jurusan Bahasa dan Sastra Indonesia UNP, dan cerpen "Orang Rantai" karya Pinto Anugrah. Data dikumpulkan dengan wawancara, transliterasi, inventarisasi data, studi pustaka, analisis dan interpretasi, dan penyimpulan. Hasil penelitian ini adalah transformasi wacana kolonial dalam teks orang rantai secara isi dipertahankan akan tetapi ada pengubahan bentuk dan gaya penceritaan berdasarkan resepsi pengarang terhadap teks orang rantai terdahulu. Transformasi teks merupakan wujud sebagai penulis tidak bisa menghindarkan diri dari pengaruh teks terdahulu dan cerita merupakan penghadiran sesuai zamannya.
\end{abstract}

Kata Kunci: transformasi, cerita kolonial, orang rantai

\begin{abstract}
The purpose of this study is to describe (1) the authors' reception of the colonial discourse in the text of "Orang Rantai"; (2) forms of transformation of the colonial story in the text of "Orang Rantai." The approach of this research is intertextuality with the application of Hans Robert Jauss's literary reception theory. The object of this research is the story of "Orang Rantai". The subject of this research is the storybook "People of the Chain" written by the Lecturers Team of the Indonesian Language and Literature Department UNP, and the short story "Orang Rantai" by Pinto Anugrah. Data collected by interview, transliteration, data inventory, literature study, analysis and interpretation, and conclusions. The result of this study is the transformation of colonial discourse in the text content of Orang Rantai is maintained, but there is a change of shapes and styles of storytelling based on the author's receptions of the text of the other Orang Rantai. Transformation of the text is a manifestation as the writer cannot avoid the influence of the preceding text, and the story is the present according to the times.
\end{abstract}

Keywords: transformation, colonial stories, Orang Rantai 


\section{PENDAHULUAN}

Sebagai salah satu negara yang pernah dijajah, Indonesia memiliki berbagai peristiwa sejarah. Peristiwa tersebut menjadi kesan yang mendalam bagi masyarakat Indonesia sehingga tidak heran banyak cerita-cerita lisan tanpa diketahui pengarangnya menyebar di berbagai daerah di Indonesia. Oleh karena itu, peristiwa masa lampau tentunya tidak semestinya menjadi jejak yang hanya menjadi catatan sejarah. Masyarakat Indonesia pun telah merekamnya menjadi cerita yang disampaikan dari mulut ke mulut yang dikenal menjadi sastra lisan.

Peristiwa sejarah yang memberikan jejak tersebut adalah kehadiran kolonial di Indonesia. Zaman kolonial hampir dirasakan oleh seluruh masyarakat Indonesia, tetapi Sawahlunto di Nagari Minangkabau Sumatera Barat lebih terkenal dengan daerah bekas jajahan Kolonial karena ada peristiwa yang begitu berkesan bagi masyarakat. Hal ini pulalah yang menarik perhatian para jurnalis yang hadir ke Sawahlunto untuk melihat langsung bekas jajahan kolonial di daerah ini.

Noor (2015) melakukan perjalanannya ke Sawahlunto dan menemukan sejarah Orang Rantai yaitu ratusan tahanan dan narapidana yang berasal dari seluruh Nusantara untuk dipekerjakan di lubang-lubang tambang. Narapidana tersebut dirantai dan bekerja menambang batu bara sampai kedalaman 15 meter. Hal yang dicatatat oleh Noor tersebutlah yang dikenal sebagai sastra lisan "Orang Rantai” di Minangkabau, kemudian oleh pemerhati Sastra di Universitas Negeri Padang dibukukan kisah Orang Rantai sebagai cerita rakyat. Bahkan, Pinto Anugrah menanggapi cerita tersebut menjadi sebuah cerpen dengan judul yang sama "Orang Rantai"

Sehubungan dengan hal tersebut, penulisan kembali cerita lisan "Orang Rantai" dengan genre yang berbeda merupakan fenomena menarik. Teeuw (2013:110) menyatakan karya sastra selalu berada dalam ketegangan antara konvensi dan invensi, sekaligus mewujudkan konvensi yang berlaku dan menyimpang dari konvensi tersebut. Dengan demikian, penulis sekaligus pembaca memberikan makna pada sebuah teks menurut harapan dan pemahamannya tentang sistem konvensi yang dianggap berlaku dalam karya tententu. Selain itu, Teeuw (2013:112) menegaskan bahwa sastra merupakan jenis undangan atau tantangan untuk melahirkan wujud baru.

Berdasarkan hal tersebutlah, konvensi jenis sastra tidak pernah seratus persen, selalu ada kelonggaran, kebebasan tertentu. Setiap penciptaan karya sastra menetapkan terwujudnya tiga jenis kenyataan dan norma, yaitu norma yang dilampaui, yang menguasai sastra sebelumnya, dan norma yang diciptakan. Oleh karena itu, perlu sebuah kajian untuk menemukan bagaimana tanggapan pembaca sekaligus penulis terhadap sebuah cerita, dalam penelitian ini adalah cerita lisan "Orang Rantai".

Sehubungan dengan penulisan kembali "Orang Rantai”, diyakini penulisan teks tersebut tidak mungkin secara ketat mematuhi teks sebelumnya. Penulisan teks tersebut tentu akan menghasilkan sebuah karya yang bersifat longgar dan lincah. Hal ini disebabkan karya sastra individual justru ditandai oleh penyimpangan dan pelanggaran norma-norma. Bahkan, bentuk perubahan yang terjadi pada teks "Orang Rantai" menjadi berbagai ganre sastra. 
Tuah Talino

Tahun XIII Volume 13 Nomor 1 Edisi 5 Juli 2019

ISSN 0216-079X

Balai Bahasa Kalimantan Barat

Dengan demikian, penulisan kembali teks "Orang Rantai” merupakan bentuk proses kreatif terhadap catatan sejarah yang kemudian menghasilkan inovasi sekaligus kontrol terhadap perubahan. Dorongan melakukan pembaharuan dan pembatasan yang diberikan oleh catatan sejarah dapat menimbulkan suasana intelektual dan sosial yang menggairahkan. Proses yang kreatif dalam pencatatan sejarah dan pembaharuan menyebabkan hasil kesusasteraan akan berkaitan dengan masalah konsep dan estetika atau puitika dari karya lain. Jadi, hal tersebut perlu diteliti dengan menggunakan teori resepsi sastra sehingga proses kreatif berupa penyalinan sebagai hasil karya kreativitas dan inovasi penulis dapat menjelaskan transformasi wacana kolonial dengan memperhatikan penulis sebagai pembaca kreatif.

Istilah kolonial selalu identik dengan penjajahan. Hal tersebut ditegaskan seperti batasan yang diungkapkan dalam KBBI (dalam jaringan) "Kolonial adalah sesuatu yang berhubungan dengan sifat jajahan." Dengan demikian, kolonial merupakan suatu kondisi yang menunjukan ada suatu pihak/kelompok yang dengan sengaja dan tersistem menjajah suatu kelompok masyarakat/wilayah. Selain itu, Edward Said (dalam Artawan dan I Nyoman, 2015:582) berpandangan bahwa stereotipe kolonial dibentuk oleh Barat atau kelas superior terhadap Timur. Timur merupakan negara bentukan yang mereka ciptakan atau sivilisasi agar menjadi beradab sebagai mana dirinya. Dengan demikian, konsep kolonial yang diacu dalam kajian ini adalah menemukan bagaimana pihak (Barat) memerlakukan masyarakat yang dijajah sebagai orang Timur yang selalu dianggap sebagai bagian yang lemah.

Resepsi sastra identik dengan pemaknaan yang diberikan oleh "pembaca". Secara lengkap resepsi sastra dimaknai sebagai bentuk reaksi atau tanggap pembaca terhadap karya sastra yang dibaca atau didengar. Tanggapan tersebut dapat bersifat pasif maupun aktif. Bersifat pasif maksudnya adalah bagaimana seorang "pembaca" dapat memahami karaya itu, atau dapat melihat hakikat estetika yang ada di dalaman karya sastra. Bersifat aktif, yaitu bagaimana ia “merealisasikan"-nya, (Junus dalam Hasanuddin, 2015:33).

Pembaca itu terdiri dari dua segi, yaitu sebagai subjek dan objek. Berdasarkan pemahaman terhadap pandangan Foulkes, Teeuw (2013:206) menyatakan bahwa sebagai subjek dialah yang membaca, menafsirkan, dan menilai karya sastra; dalam proses interpretasi dia selalu berada dalam tegangan antara struktur teks sebagai sesuatu yang diberikan secara optimal di luar dirinya. Sebagai objek, pembaca yang sadar atau tidak sadar, terkena berbagai pengaruh dan kekuatan sosial, politik, budaya dari teks yang dibacanya.

Hans Robert Jauss (dalam Susanto, 2011:211) telah mengenalkan satu pendekatan terhadap sejarah sastra dengan menitikberatkan pada tanggapan dari pembaca. Menurut Hans Robert Jauss, teori dasar teori estetika resepsi yang dia kembangkan oleh dirinya merupakan satu usaha untuk memberikan jembatan antara dua tradisi dalam teori kesusasteraan yakni tradisi formalistik dan marxisme. Estetika resepsi sendiri pada hakikatnya merupakan satu sintesis dari teori puitik dan juga teori penafsiran atau sering disebut dengan hermeneutika.

Hans Rober Jauss (dalam Susanto, 2011:213-2016) mengenalkan tujuh tesis yang diantaranya adalah pengalaman membaca, horizon harapan, jarak 
Tuah Talino

Tahun XIII Volume 13 Nomor 1 Edisi 5 Juli 2019

ISSN 0216-079X

Balai Bahasa Kalimantan Barat

estetik, semangat zaman, rangkaian sastra, sinkronik dan diakronik, dan sejarah khusus dan sejarah umum. Berikut dirincikan ketujuh tesis menurut Jauss tersebut.

Perkembangan sastra dan masyarakat memiliki keterkaitan dalam penciptaan karya sastra sehingga sastra bagaikan refleksi fakta kemasyarakatan. Kristeva (dalam Teeuw, 2013:147) mengungkapkan bahwa setiap teks sastra merupakan pengungkapan dan transformasi teks-teks lain. Anggapan ini menimbulkan konsekuensi bahwa sebuah karya sastra hanya dapat dibaca dalam hubungannya dengan teks-teks lain. Prinsip intertekstualitas ini memperjelas makna teks, baik teks yang disambut maupun teks yang menyambut. Dengan demikian, prinsip intertekstualitas ini merupakan satu fase yang harus dilewati pembaca. Riffaterre (dalam Zaimar, 1990:25) menyatakan,

Interteks adalah keseluruhan teks yang ada di depan kita, keseluruhan teks yang dapat ditemukan dalam pikiran seseorang ketika membaca suatu bagian teks. Jadi, interteks adalah korpus yang tidak terbatas. Memang, bisa saja ditemukan bagian awalnya: itu adalah teks yang membangkitkan asosiasi segera setelah kita mulai membaca. Sebaliknya, jelas tak akan terlihat bagian akhirnya. Banyak tidaknya asosiasi ini tergantung dari luasnya pengetahuan budaya si pembaca. Pengenalan interteks yang ada sebelumnya timbul dari pengaruh warisan sastra, dari penelitian tradisional tentang sumber, suatu tradisi yang pada masa kini kurang dihargai. Pengenalan tentang interteks yang datang kemudian timbul dari sejarah keabadian suatu karya sastra.

Dengan demikian, teks-teks yang terpadu dalam sebuah teks sastra dapat tertulis dan dapat pula tidak tertulis. Hal terpenting adalah asosiasi pemikiran pembaca sewaktu membaca sebuah teks. Pengalaman membaca teks lain akan memberi pengaruh terhadap hasil pembacaan saat ini. Pengarang yang sekaligus sebagai pembaca akan menuangkan semua pengaruh yang ada di dalam karya yang ditulisnya. Oleh sebab itu, penyaduran akan sangat memungkinkan muncul penafsiran yang baru dari teks-teks sebelumnya.

\section{METODE}

Jenis penelitian ini adalah penelitian deskriptif kualitatif yang bersifat analisis isi. Subjek penelitian ini adalah cerita Orang Rantai dari teks yang sama dalam bentuk atau genre yang berbeda, baik dalam bentuk lisan dan buku yang telah diterbitkan maupun dalam bentuk naskah dan responden yang mengetahui cerita lisan "Orang Rantai". Subjek penelitian ini dikategorikan pada dua jenis, yaitu (1) teks sambutan, yaitu teks yang dianggap sebagai dasar penciptaan, yaitu Cerita Lisan "Orang Rantai" dan (2) teks penyambut, yaitu teks yang ditulis kemudian dengan meneladankan teks-teks sambutan. Teks penyambut adalah Cerita Sejarah Orang Rantai: Dari Penjara ke Penjara yang ditulis oleh Dinas Pariwisata dan Kebudayaan Kota Sawahlunto pada tahun 2017 yang diterbitkan oleh Ombak di Yogyakarta dan cerpen "Orang Rantai" karya Pinto Anugrah. Objek penelitian ini adalah wacana kolonial dalam teks "Orang Rantai" . Cerpen "Orang Rantai" merupakan salah satu cerpen karya Pinto Anugrah yang terdapat dalam sebuah antologi cerpen berjudul Kumis Penyaring Kopi. Antologi ini 
Tuah Talino

Tahun XIII Volume 13 Nomor 1 Edisi 5 Juli 2019

ISSN 0216-079X

Balai Bahasa Kalimantan Barat

diterbitkan pada tahun 2012. Teknik pengumpulan dan analisis data dalam penelitian ini digunakan empat hal, yaitu (1) Inventarisasi sumber data, (2) Identifikasi data, (3) Analisis dan interpretasi, dan (4) Penyimpulan.

\section{HASIL DAN PEMBAHASAN}

\section{Resepsi Penulis terhadap Wacana Kolonial dalam teks "Orang Rantai"}

Resepsi penulis atau pengarang dalam hal ini dimaknai sebagai pembaca kreatif yang menghasilkan karya berdasarkan tanggapannya terhadap teks terdahulu. Teks yang diresepsi adalah cerita rakyat "Orang Rantai". Berikut dapat digambarkan resepsi penulis terhadap wacana kolonial dalam dua teks, yaitu Cerita "Sejarah Orang Rantai: Dari Penjara ke Penjara" yang ditulis oleh Dinas Pariwisata dan Kebudayaan Kota Sawahlunto pada tahun 2017 yang diterbitkan oleh Ombak di Yogyakarta dan cerpen "Orang Rantai” karya Pinto Anugrah.

Wacana kolonial yang diresepsi oleh Dinas Pariwista dan Kebudayaan Sawahlunto dapat dijelaskan sebagai berikut. Cerita "Orang Rantai" bercerita tentang sejarah keinginan Kolonial datang ke Sawahlunto yang secara wilayah termasuk wilayah kecil. Cerita tersebut digambarkan sebagai berikut.

Van Kool sengaja datang ke Sawahlunto pada tahun 1901. Tentu saja kita heran, apa sebab Menteri Koloni Belanda justru mau datang ke kampung kecil itu di tengah hutan belantara itu? Emas Hitam!!!! Emas Hitam!!!. Ya, Emas Hitam atau batubara yang berada di perut bumi Sawahlunto membuat para petinggi rela datang. Batubara dan Orang Rantai adalah dua kata yang membuat para petinggi Belanda sibuk untuk mengais keuntungan dengan menggunakan sistem perbudakan. (Dinas Pariwisata dan Kebudayaan, 2007).

Kutipan tersebut menunjukkan penulis sebagai pembaca dan pendengar cerita lisan "Orang Rantai" meresepsi wacana kolonial dengan menggambarkan maksud dan tujuan para petinggi Belanda datang ke Sawahlunto. Keinginan mendapatkan keuntungan besar tanpa mengeluarkan modal menyebabkan para tahanan, para pemberontak Belanda, menjadi tenaga kerja untuk memuaskan kehendak Belanda. Berikut bentuk resepsi pembaca kreatif.

Batubara yang ditemukan oleh insinyur muda Belanda, W.H. de Greeve di wilayah Sawahlunto dan Sijunjung pada tahun 1868 itu memang menjanjikan. Penemuan itu menggegerkan negeri Belanda. Kampung kecil Sawahlunto mendadak jadi pergunjingan di kalangan para petinggi Belanda. Saking banyaknya yang menawarkan diri menjadi investor, menteri koloni di Den Haag malah bingung, apalagi Gubernur Jenderal di Batavia. Siapa yang mau mengeksploitasinya? Kalau pemerintah tidak punya modal, kalau investor, ya sayang sekali, karena pemerintah Belanda dalam abad emperium perlu batubara. Tarik ulur dalam diskusi Parlemen Belanda di Den Haag terjadi. Sudah ditenderkan berkali-kali ke pihak swasta, tetapi ya...namanya pemerintah Belanda ingin menguasainya. Baru tahun 1892 resmi batubara menjadi perusahaan negara (Belanda). (Dinas Pariwisata dan Kebudayaan, 2007). 
Tuah Talino

Tahun XIII Volume 13 Nomor 1 Edisi 5 Juli 2019

ISSN 0216-079X

Balai Bahasa Kalimantan Barat

Kisah selanjutnya pun masih mempertegas bahwa niat keji Belanda untuk memperoleh keuntungan. Sengaja mencari para narapidana dan orang-orang yang memberontak untuk menjadi pekerja tambang batu bara ataupun yang membuat rel kereta api. Berikut kutipan ceritanya.

Direktur kehakiman mencari para napi dari penjara-penjara di pulau Jawa. Penjara-penjara di kota Surabaya, penjara Glodok, penjara Cipinang di Batavia sudah penuh sesak oleh para napi politik dan kriminal. Nah, ini tenaga kerja yang luar biasa untuk tambang batubara, gumam Direktur penjara yang memerintahkan anak buahnya menghitung jumlah napi yang akan diangkut ke 'penjara' Sawahlunto. (Dinas Pariwisata dan Kebudayaan, 2007).

"Mampus Kowe akan dipindahkan dari penjara sini ke penjara Sawahlunto, jauh, di tengah hutan belantara, kata petugas penjara dengan garangnya sambil memperlihatkan seolah-olah dia lah yang berkuasa penuh di sana. Satu per satu dipilihlah laki-laki yang berbadan tegap, masih muda, lalu dibawa ke pelabuhan Tanjung Periuk untuk kemudian dikapalkan ke pelabuhan Emma Haven (Teluk Bayur) yang sudah selesai dikbangun, sebelum tambang Sawahlunto dibuka tahun 1892. Tidak peduli, apakah mereka napi politik atau napi kriminal, semua dicampurbaur. (Dinas Pariwisata dan Kebudayaan, 2007).

Kutipan-kutipan tersebut merupakan penggambaran wacana kolonial yang dipertahankan oleh Dinas Pariwisata dan Kebudayaan Sawahlunto. Selain mempertahankan kosep kolonial, Dinas Pariwisata juga mengembangkan cerita "Orang Rantai" dengan penggambaran beberapa tokoh yang menjadi orang pesakitan atau sebagai tenaga tambang untuk pihak Belanda. Beberapa tokoh yang diceritakan adalah sebagai berikut.

Ada seorang pendekar sakti dikjaya di dunia persilatan di pulau Bangka. Sebut saja Kakek Udin... ia mempunyai banyak murid. Mereka datang dari mana-mana untuk berlatih silat, mempertahankan negeri dari ancaman kekuasaan Belanda. Takut menjadi 'pengacau' Belanda di pulau timah itu, Belanda memenjarakan pendekar sakti ini, mengusirnya dari Bangka, dikirim dan menjadi orang rantai Sawahlunto.

Kalau di Batavia nama-nama seperti Usup, Entong dan Mamang tak asing lagi. Orang-orang Betawi begitu takut kepada mereka. Mereka merampok rumah-rumah Belanda di daerah Meester Cornelis (Jatinegara), Kemayoran dan Kota. Mereka ditangkap dan dijebloskan ke penjara Cipinang dan Glodok. ... Belanda tentu saja gusar. Akhirnya mereka dikirim ke Sawahlunto, menjadi kuli paksa pemecah batubara di sana.

Mbah Wongso Karyo. Ia adalah salah seorang perantaian yang berani dan terkenal bringas. Ia dikirim Belanda ke Sawahlunto karena memberontak. Pasalnya bermula ketika Belanda mengambil tanahnya secara paksa di Jawa. Ia jengkel dan pada suatu malam, dengan mengendap-endap ia mendatangi rumah Belanda dan kemudian membakarnya. Ia kemudian dihukum dan dikirim ke Sawahlunto. 
Tuah Talino

Tahun XIII Volume 13 Nomor 1 Edisi 5 Juli 2019

ISSN 0216-079X

Balai Bahasa Kalimantan Barat

Kartowiyono lahir pada tahun 1888. dalam usia muda belia, 25 tahun, ia dikirim ke Sawahlunto.... ia bukan seorang pembunuh atau perampok. Akan tetapi, ia dikirim ke Sawahlunto karena selalu memberontak terhadap Belanda. Jadilah ia tahanan politik Belanda yang dirantai kakinya dan ditato tangannya. (Dinas Pariwisata dan Kebudayaan, 2007).

Kutipan tersebutlah yang menjelaskan tokoh-tokoh yang dihadirkan penulis adalah resepsi penulis terhadap kelicikan Belanda sebagai Kolonial sehingga orang-orang yang menentang mereka akan menjadi korban. Selain resepsi dinas pariwisata dan kebudayaan Sawahlunto yang meresepsi dengan mempertahankan cerita sejarah dalam cerita "Orang Rantai", berikut resepsi dalam teks kedua yaitu Cerpen "Orang Rantai" karya Pinto Anugrah.

Pinto Anugrah dalam cerpennya bercerita tentang kehidupan sebuah keluarga. Keluarga yang terdiri atas Bapak, Mak, dan Saya adalah keluarga yang sebenarnya berasal dari Jawa. Bapak merupakan tokoh yang digambarkan bekerja sebagai kuli kontrak. Bapak bertugas memindahkan batu bara dari atas lori ke dalam tungku di sebuah perusahaan batu bara milik Belanda. Pinto Anugrah sebagaimana teks sebelumnya mempertahankan wacana kolonial pada Belanda sebagai penguasa yang tega menindas dan ingin meraih keuntungan besar. Hal ini terlihat dalam cerpen "Orang Rantai", yaitu sebagai sebuah perusahaan milik Belanda, peraturan bagi pekerja sangat ketat. Upah pun terbilang kecil.

Selanjutnya Pinto meresepsi para pekerja yang terdapat pada cerita sejarah orang rantai melalui tokoh Bapak yang akhirnya menjadi orang rantai oleh Belanda, berikut gambaran Pinto. Suatu hari, Bapak terlibat pertengkaran di tempat judi di pasar malam yang mengakibatkan seorang Indo Belanda terbunuh. Bapak menjadi tersangka dan ditangkap oleh segerombolan polisi yang bersenjata laras panjang. Bapak dibawa polisi itu dan menurut opas penjaga Goedang Ransoem, Samin dan Amaik, dia dijadikan orang rantai. Orang rantai adalah sebutan bagi para pekerja paksa di lubang tambang dalam Sungai Durian yang kakinya selalu dirantai sehingga tidak dapat melarikan diri. Mereka yang menjadi orang rantai adalah narapidana yang dijadikan kuli karena merampok dan membunuh.

Selanjutnya, cerita dikembangkan pada tokoh Saya dalam cerpen "Orang Rantai”, yaitu tokoh Saya diceritakan terus mengalami mimpi buruk tentang keberadaan orang rantai. Tokoh Saya selalu gelisah karena dalam mimpi itu dia menyaksikan bagaimana para orang rantai dijadikan kuli dan ditindas secara tidak manusiawi. Kondisi ini menggambarkan situasi kolonial pada masa penjajahan Belanda dengan menunjukkan adanya penindasan yang dilakukan oleh Belanda sebagai pemilik gudang batu bara terhadap kuli kontrak dan orang rantai.

Pinto dalam cerpennya meresepsi wacana kolonial dengan mempertahankan kosep orang rantai, yaitu bentuk dari ketertindasan. Orang merupakan bentuk representasi tubuh yang dijadikan sebagai ruang yang semestinya memiliki kebebasan. Sementara itu, rantai merupakan simbol yang diartikan sebagai pembatas kebebasan yang dimiliki oleh tubuh. Situasi ketertindasan dihadirkan dalam bentuk nyata dalam mimpi. Hal ini seperti kutipan cerpen "Orang Rantai" sebagai berikut. 
“Tidak!” Aku terbangun. Mimpi itu lagi. Oh, mimpi dalam mimpi. Benarkah ketakutan itu. Aku mencoba bangkit dari tempat tidur hendak membasuh muka. Menghilangkan rasa takut. Namun rasanya tubuh ini nyeri digerakkan. Kuperiksa tubuhku; perut, dada, dan punggungku memar seperti bekas cambukan. Kakiku, terasa berta dilangkahkan dan dipergelangan kakiku memar bekas dirantai. Pergelangan tanganku juuga memar dan sulit digerakkan. Aku sulit bernapas. Napasku sesak seperti ada yang mencekik. Kuraba leher ini, memar, perih, kulitnya lunak. Aku semakin tercekik. Oh, aku ngat cerita guru itu; orang rantai. Apakah aku? Darahku serasa habis. Kemudian gelap. Kelam (Anugrah, 2012).

Pemaknaan orang rantai pada cerpen tersebut semakin mengukuhkan wacana kolonial, yaitu menunjukkan adanya tubuh yang berada pada posisi subordinat karena dibelenggu oleh rantai yang dapat membatasi ruang geraknya. Tokoh Bapak dijadikan sebagai orang rantai berposisi sebagai sosok yang dipinggirkan dan diberi perlakukan yang berbeda atau ditindas. Tokoh Bapak tidak diberi ruang sebagai subjek yang dapat menentukan sikap, tetapi dihadirkan sebagai objek yang dikenai perlakuan oleh tokoh lain dalam hal ini adalah Belanda. Semantara itu, tokoh Saya hadir mendobrak penindasan itu dan membebaskan tokoh Bapak meskipun pada akhirnya tidak berhasil dan bahkan justru dia turut merasakan dirinya berada dalam penindasan layaknya orang rantai.

"Tolong izinkan saya masuk. Saya ingin menemani Bapak."

Saya terus memaksa masuk. Tapi tubuh dua orang polisi itu begitu kekar dan kuat, sulit untuk menerobosnya. Sepertinya dua polisi itu sudah muak melihat tingkah saya, mereka menyeret dan melempar saya ke sungai, seperti mereka melemparkan bangkai anjing (Anugrah, 2012).

\section{Bentuk-bentuk transformasi cerita kolonial dalam teks "Orang Rantai"}

Berikut dijelaskan bentuk-bentuk transformasi cerita kolonial dalam teks "Orang Rantai". Tranformasi pada sebuah teks dapat dinyatakan sebagai sebuah perkembangan tanggapan pembaca terhadap teks "Orang Rantai". Kerangka perkembangan ini dapat ditelaah berdasarkan hakikat sastra, yaitu pada dua hal penting. Pertama, unsur cerita, yang dapat disederhanakan dalam berbagai isi. Kedua, unsur yang menguraikan cerita, menggunakan bahasa sebagai alat, lebih dikenal dengan istilah bentuk atau teknik penceritaan.

Penelusuran tanggapan pembaca terhadap teks "Orang Rantai" dimulai dari segi bentuk kemudian diikuti oleh segi isi. Hal tersebut disesuaikan prinsip intertekstualitas. Prinsip tersebut memposisikan suatu teks dalam sistem sastra dengan memperhatikan hubungan dan kesinambungan antara teks penyambut dengan teks lain sebagai teks sambutan, secara sinkronis dan juga secara diakrnonis.

\section{Tranformasi Bentuk}

Penelurusan tanggapan pembaca ataupun sebagai penulis pada cerita 'Orang Rantai” dalam bentuk cerita sejarah dan cerpen sudah menjelaskan terjadi transformasi bentuk yang tegas dalam penyampaian cerita. Beberapa hal yang menunjang penjelasan tersebut adalah sebagai berikut. (1) Pada teks sambutan, teks diceritakan dengan pola naratif sementara pada teks penyambut tidak diceritakan karena hadir sendiri. (2) Bentuk teks sambutan yang dipilih oleh 
pembaca atau penulis adalah cerita rakyat/sastra lisan. Bentuk teks penyambut yang dipilih adalah cerita sejarah dan cerpen.

Hal tersebut senada dengan yang disampaikan oleh Junus (1993:12), yaitu pendekatan formalistik dapat dibedakan antara unsur bentuk dan isi sesuai dengan tingkat kepentingannya. Pandangan pendekatan formalistik, bentuk bersifat netral, hanya alat, dan dianggap tidak memiliki pengaruh apa pun terhadap isi. Junus (1989:12) pun menambahkan bahwa kini telah ada hubungan antara bentuk dan isi sehingga bukan lagi suatu "tanpa makna" atau hanya sekadar alat isi. Berikut dijelaskan transformasi bentuk dalam hal aspek bercerita dan diceritakan serta aspek fungsional bentuk teks.

\section{Aspek 'Bercerita" dan Aspek "Diceritakan"}

Teks penyambut cerita sejarah "Orang Rantai" menceritakan secara jelas sejarah kolonial yang mengambil kekayaan di daerah Sawahlunto. Penggambaran orang rantai dalam cerita sejarah ini dideskripsikan secara jelas siapa-siapa saja yang menjadi tokoh utama sebagai gambaran mengapa mereka dipekerjakan untuk menambang batubara oleh Belanda. Sebagai teks penyambut, cerita sejarah ini lebih lengkap menceritakan teks sambutan, yaitu cerita rakyat yang diketahui dari mulut-kemulut oleh masyarakat Minangkabau.

Sementara itu, cerpen "Orang Rantai" sebagai teks penyambut tidak menceritakan secara rinci tentang orang rantai dalam sejarahnya. Teks penyambut ini menggambarkan dengan menyesuaikan zaman penciptaan. Cerita dihadirkan dalam alam mimpi, yaitu pada tokoh Saya yang menjadi pintu untuk mengenal bagaimana orang rantai diperlakukan oleh Belanda. Dengan demikian, wacana kolonial tetap dinarasikan dengan penceritaan yang berbeda.

\section{Aspek Fungsional Tranformasi Bentuk Teks}

Tanggapan pembaca selanjutnya dapat dilihat pada aspek fungsionalnya, yaitu apakah ada hubungan signifikan antara bentuk yang dipilih dengan aspek cerita (isi) yang dikomunikasikan. Pemilihan bentuk penyampaian berupa cerita sejarah dan cerpen, yaitu suatu bentuk sastra yang merupakan narasi lengkap tentang peristiwa. Perubahan bentuk tidak terjadi begitu gambalng sehingga menunjukkan adanya pemertahanan wacana kolonial dalam teks sebagai bentuk merekam cerita sejarah agar diketahui generasi bangsa.

Teks sambutan berupa cerita sejarah merupakan hasil transformasi dari bentuk sastra lisan dan bentuk lain sebelumnya. Bentuk tersebut dianggap tidak memiliki nilai fungsional karena menyampaikan hal yang sama. Oleh karena itu, pada teks sambutan membenarkan teori yang berpendapat bahwa antara bentuk dan isi tidak memiliki fungsional, yaitu sesuatu yang mutual exclusive, bentuk hanyalah sekadar alat untuk menyampaikan isi.

\section{Tranformasi Isi}

Berdasarkan pembahasan pada bagian sebelumnya, yaitu wacana kolonial dan orang rantai baik yang terdapat pada teks sambutan maupun pada teks penyambut, yaitu telah terjadi transformasi nilai tentang bagaimana memahami nilai kemanusiaan dari perlakuan kolonial. Junus (1981:84) menyatakan suatu karya sastra, terutama cerita, seperti novel, drama, atau cerpen, bukan sekadar sastra lama/klasik tetapi sastra modern yang merupakan suatu mitos. Oleh karena 
Tuah Talino

Tahun XIII Volume 13 Nomor 1 Edisi 5 Juli 2019

ISSN 0216-079X

Balai Bahasa Kalimantan Barat

itu, proses transformasi dapat digambarkan mitos apa yang dikembangkan sebuah teks penyambut.

\section{Mitos Pengukuhan dan Mitos Pembebasan}

Mitos tumbuh dan berkembang pada masyarakat tradisional yang berkaitan dengan kondisi masyarakatnya. Pada sastra tradisional, mitos lebih penting dari pada cerita lain yang ada dalam kebudayaan verbal suatu masyarakat. Dalam kondisi seperti itu, masyarakat tidak menyadari bahwa mereka sedang berhadapan dengan mitos. Ketika kesusasteraan dan masyarakat pendukung terasa akrab, pada posisi inilah kesusasteraan mengemban fungsi sosial efektif.

\section{Aktualisasi Nilai-Nilai Tradisi melalui Mitos Pengukuhan}

Berdasarkan hasil analisis pada wacana kolonial dan orang rantai, yaitu melalui identifikasi hubungan antarperan dan interkasinya dengan tokoh lain, serta keterlibatan dengan rangkaian peristiwa, dirumuskan mitos pada teks penyambut. Mitos pada teks penyambut merupakan pro-mitos pada teks sambutan. Dengan demikian, mitos dalam teks penyambut disebut mitos pengukuhan, berikut diuraikan pada cerita sejarah orang rantai dan cerpen "Orang Rantai" Karya Pinto Anugrah.

Cerita sejarah mengukuhkan wacana kolonial dengan menghadirkan sejarah Belanda membawa para narapidana ke Sawahlunto dan dipekerjakan sebagai pekerja tambang. Cerita sejarah juga menjabarkan bagaimana orang rantai dipaksa bekerja tanpa mengenal belas kasihan. Berikut dapat dilihat dalam kutipan berikut.

Tanpa menunggu waktu lama, orang-orang rantai dibagi kerjanya, persis seperti pembagian kerja sapi gemuk dan sapi kurus. Mereka yang memiliki fisik yang kuat, yang gemuk, disuruh bekerja dalam lobang, memecah arang, memikul kayu-kayu balok berat ke dalam lobang untuk penyangga lobang tambang. Pekerjaan di lobang memang berat. Tidak ada kata ampun. Para napi yang memiliki fisik lemah, disuruh menjadi perawat teman-temannya yang sakit atau melakukan pekerjaan ringan seperti menyeleksi batubara menurut ukurannya. (Dinas Pariwisata dan Kebudayaan, 2007).

Selain itu, cerita sejarah orang rantai yang diceritakan oleh Dinas Pariwisata dan Kebudayaan juga mengukuhkan kolonial adalah orang yang tidak memiliki belas kasihan yang dipentingkan hanya keuntungan mereka. Berikut penggambarannya.

Para petinggi Ombilin atau pejabat Belanda tak perduli apapun yang terjadi di dalam lobang. Yang terpenting, target produksi tercapai, laba bisa diraih. Apalagi mereka akan menikmati komisi untuk setiap ton batubara yang diproduksi. Komisi tidak hanya akan membuat mereka menjadi kaya, juga membuat hidup lebih menyenangkan. Mereka bisa plesiran di akhir minggu ke pesanggrahan yang ada di daerah Matur, arah ke Maninjau. (Dinas Pariwisata dan Kebudayaan, 2007).

Teks penyambut kedua adalah cerpen "Orang Rantai" karya Pinto Anugrah. Cerpen tersebut mengukuhkan wacana kolonial dengan menghadirkan cerita Saya 
Tuah Talino

Tahun XIII Volume 13 Nomor 1 Edisi 5 Juli 2019

ISSN 0216-079X

Balai Bahasa Kalimantan Barat

dan Bapak. Cerita orang rantai tersebut selain menunjukkan orang sebagai tubuh atau ruang yang terjajah juga menunjukkan adanya waktu yang terdiri dari waktu dunia nyata dan waktu dunia mimpi. Penggambaran dalam cerpen tersebut waktu di dunia nyata lebih sempit dibandingkan waktu dunia mimpi. Waktu di dunia mimpi memungkinkan penjelajahan yang lebih dalam dan luas. Sementara waktu di dunia nyata terbatas. Ini berarti waktu di dunia nyata memberi batasan terhadap ruang gerak subjek, sementara waktu di dunia mimpi memberi kebebasan ruang gerak subjek.

Tokoh saya mengalami waktu di dunia nyata dan waktu di dunia mimpi. Ketika berada pada waktu di dunia nyata, dia tidak dapat menemukan keberadaan orang rantai. Ketika dia berada pada waktu di dunia mimpi, dia bahkan dapat merasakan dirinya sebagai orang rantai. Waktu di dunia mimpi memberikan gambaran kepada tokoh tentang situasi yang tidak dia alami sendiri namun dia seakan-akan dapat merasakannya sendiri. Tokoh Bapak yang berada di masa lalu seakan dapat dihadirkan kembali oleh toko saya melalui dunia mimpinya. Ini berarti waktu dunia mimpi dapat menghidupkan kembali yang telah mati, menghadirkan kembali yang telah pergi, dan mengadakan kembali yang tiada. Oleh karena itu, situasi kolonial di masa lalu hadir ketika tokoh saya dalam dunia mimpi dan situasi poskolonial hadir ketika tokoh saya dalam dunia nyata. Situasi poskolonial ini disajikan dalam cerita.

"Ini, bukanlah kehidupan senja di pegunungan yang sepi. Kota ini, kota yang membara oleh batubaranya. Kota yang terletak pada sebuah lembah, dikurung oleh perbukitan, hingga jika dilihat dari salah satu puncaknya persis seperti kuali. Kota kuali. Tapi jangan pernah membayangkan, karena letak topografisnya kota ini kota yang sejuk, yang setiap saat akan berhembus angin gunung atau angin lembah. Kota ini berdebu dengan suhu yang amat panas, apalagi jika siang hari” (Anugrah, 2012).

Selain itu, di dalam cerpen ini juga dihadirkan interpretasi kota dan desa yang sering kali berbeda. Desa adalah tempat nyata bagi orang desa sedangkan kota hadir sebagai utopia yang dibayangkan sebagai sesuaitu yang ideal. Cerpen ini sengaja menggunakan diksi "kota", tetapi kota yang dihadirkan tidak seperti yang diharapkan. Kota adalah tempat yang sibuk. Kota adalah keterbatasan. Kota adalah tempat yang membelenggu.

"Sawahlunto, begitulah nama resmi kota ini. Dapat dikatakan bahwa kota ini kota yang sibuk. Pecahan batubara terserak dimana-mana. Lori-lori hilir mudik mengangkut batubara dari lubang-lubang tambang yang tak jauh dari pusat kota. Tiap sebentar kereta api akan berangkat dan berhenti di stasiun mengangkut emas hitam itu ke pelabuhan" (Anugrah, 2012).

Selanjutnya, cerpen ini juga menghadirkan sudut pandang dari sisi penjajah. Pemilik perusahaan batu bara asal Belanda dihadirkan sebagai sosok penjajah. Selain pemilik perusahaan (Belanda), polisi dan penjaga gudang juga hadir sebagi penjajah. Penjajah digambarkan dapat mengatur dan mengambil kebijakan sesuai keinginannya, termasuk dia berhak menentukan siapa saja yang bisa dijadikan sebagai orang rantai. Penjajah di sisi yang lain dapat mengamankan tubuh si 
Tuah Talino

Tahun XIII Volume 13 Nomor 1 Edisi 5 Juli 2019

ISSN 0216-079X

Balai Bahasa Kalimantan Barat

terjajah melalui ruang baru yang dibangun atau disediakan bagi tubuh itu yaitu dengana adanya barak tempat tinggal.

\section{PENUTUP}

Berdasarkan hasil penelitian dan pembahasan yang telah dipaparkan pada bagian sebelumnya, dapat dikemukakan simpulan sebagai berikut. Resepsi penulis sebagai pembaca kreatif yang menghasilkan karya berdasarkan tanggapan terhadap terhadap wacana kolonial dalam teks orang rantai digambarkan dalam teks penyambut, yaitu cerita sejarah orang rantai: dari penjara ke penjara yang ditulis oleh Dinas Pariwisata dan Kebudayaan Sawahlunto dan cerpen "Orang Rantai" karya pinto Anugrah. Resepsi dalam kedua teks tersebut terhadap wacana kolonial sama, yaitu kolonial adalah sosok yang menindas kaum lemah untuk meraup dan memeroleh keuntungan yang besar serta sosok yang ingin menguasai daerah jajahan tanpa mengenal takut.

Transformasi yang dihadirkan dari teks sambutan adalah berupa teks prosa yang menarasikan kembali cerita lisan "Orang Rantai". Transformasi bentuk dalam teks penyambut adalah (1) Pada teks sambutan, teks diceritakan dengan pola naratif sementara pada teks penyambut tidak diceritakan karena hadir sendiri. (2) Bentuk teks sambutan yang dipilih oleh pembaca atau penulis adalah cerita rakyat/sastra lisan. Bentuk teks penyambut yang dipilih adalah cerita sejarah dan cerpen.

Transformasi isi teks, yaitu pada wacana kolonial dan orang rantai yang terdapat pada teks sambutan maupun pada teks penyambut, yaitu telah terjadi transformasi nilai tentang bagaimana memahami nilai kemanusiaan dari perlakuan kolonial. Hasil analisis pada wacana kolonial dan orang rantai, yaitu melalui identifikasi hubungan antarperan dan interkasinya dengan tokoh lain, serta keterlibatan dengan rangkaian peristiwa, dirumuskan mitos pada teks penyambut. Mitos pada teks penyambut merupakan pro-mitos pada teks sambutan, yaitu mitos pengukuhan.

\section{DAFTAR PUSTAKA}

Anugrah, Pinto. (2012). “Orang Rantai”. Kumis Penyaring Kopi. Yogyakarta: Ning.

Artawan, I Gde dan I Nyoman Yasa. (2015). "Mimikri dan Steriotip Kolonial terhadap Budak dalam Novel-Novel Balai Pustaka". Jurnal Ilmu Sosial dan Humaniora, Vol. 4, No. 1.

Dinas Pariwisata dan Kebudayaan. (2007). Cerita Sejarah Orang Rantai: Dari Penjara- ke Penjara. Sawahlunto: Dinas Pariwisata dan Kebudayaan.

Hasanuddin WS. (2015). Transformasi Budaya dan Produksi Sosial Teks. Bandung: Angkasa Bandung.

Junus, Umar. (1981). Mitos dan Komunikasi. Jakarta: Sinar Harapan.

Sejarah. Kuala Lumpur: Dewan Bahasa dan Pustaka.

-. (1993). Dongeng tentang Cerita. Kuala Lumpur: Dewan Bahasa dan

Pustaka. 
Tuah Talino

Tahun XIII Volume 13 Nomor 1 Edisi 5 Juli 2019

ISSN 0216-079X

Balai Bahasa Kalimantan Barat

Noor, Ronal. (2013). "Sawahlunto: Menelusuri Jejak Kolonial dan Orang Rantai" kompasiana." ,online (http://www.kompasiana.com/ronaldr/sawahluntomenelusuri-jejak-kolonial-dan-orang-rantai_552caeed6ea834c6448b4586) diakses, 20 Januari 2017.

Susanto, Dwi. (2011). Pengantar Teori Sastra. Yogyakarta: Caps.

Teeuw, A. (2013). Sastra dan Ilmu Sastra. Jakarta: Pustaka Jaya.

Wellek, Rene dan Austin Warren. (2014). Teori Kesusastraan (terjemahan Melani Budianta). Jakarta: Gramedia Pustaka Utama. 